\title{
Beşiktaş'ın 19. Yüzyıldaki Kentsel Dönüşümüne Bir Bakış
}

\author{
Murat ÇAĞLAYAN ${ }^{1}$
}

Atıf/C): Çağlayan, Murat, Beşiktaş'ın 19. Yüzyıldaki Kentsel Dönüşümüne Bir Bakış, Artuklu İnsan ve Toplum Bilim Dergisi 2020/5 (1), 33-52.

Öz

Ondokuzuncu yüzyıl, Osmanlı Devleti'nin modernizasyonu için önemli bir dönemdir. Şüphesiz batılılaşmanın somut delilleri, ilk olarak devletin başkenti İstanbul'da görülmeye başlamıştır. Bu yüzyılda modern şehircilik uygulamaları bağlamında Beyoğlu ile beraber Beşiktaş ilçesi önemli bir yer tutar. Ondokuzuncu yüzyılda Beşiktaş'ın bir yönetim merkezi olması onu öteki semtlerden farklı kılar. Şüphesiz ondokuzuncu yüzyıl öncesindeki yaşananlar bu dönemdeki ortamın hazırlanmasına vesile olmuştur. Aynı şekilde bu asırda yaşananlar, cumhuriyet dönemi Beşiktaşına da yön vermiştir. Bu sebeple makale; Beşiktaş'ın ondokuzuncu yüzyıldaki dönüşüm anlayışından önce Cumhuriyet ve ondokuzuncu yüzyıl öncesi tarihi gelişimlere de değinmektedir. Saray idaresinin ve dolayısıyla yönetici, memur sınıfının semte taşınması ile Beşiktaş’ta şehircilik ve sosyal açıdan bir dönüşüm başlamıştır. Çalışmanın amacı, bu dönemde Beşiktaş semtinde meydana gelen dönüşümleri neden sonuç çerçevesinden incelemektir. İstanbul'un genel çehresinde görülen değişim ve dönüşümler saray olgusu ile Beşiktaş’ta hızlı yaşanmıştır. Bu yüzyılda kentsel dönüşümleri, mimariyi dolayısıyla sosyal yapıyı ve ekonomik durumu etkileyen bir döngüsel bir süreç tanımlanabilir. Başka bir ifadeyle Beşiktaş'a sarayla birlikte gelen zengin halkın ekonomik gücü ve sosyal yaşantısı mimariye, kentsel ve sosyal dokuya yansımıştır.

Anahtar Kelimeler: Mimarlık, Ondokuzuncu Yüzyıl, Osmanlı, Beşiktaş, Kentsel Dönüşüm.

\section{A Glance on Beşiktaş's $19^{\text {th }}$ Century Urban Transformation}

Citation/C): Çağlayan, Murat, A Glance on Beşiktaş's $19^{\text {th }}$ Century Urban Transformation, Artuklu Human and Social Science Journal 2020/5 (1), 33-52.

\section{Abstract}

The nineteenth century is an important period for the modernization of the Ottoman Empire. Undoubtedly, concrete evidence of westernization started to appear first in the capital of the state, Istanbul. Besiktas has an important place in the context of modern urbanism practices with beyoglu. The fact that Besiktas was a royal administrative center in this century makes it different from other districts. Undoubtedly, what happened before the nineteenth century was instrumental in preparing the environment in this period. Likewise, what happened in this century gave the direction to the Besiktas's of the republican period. For this reason, the article also addresses the historical developments before the republican period and nineteenth-century before Besiktas's understanding of the transformation in the nineteenth century. Urbanization and social transformation started in Besiktas with the transfer of the royal administration society and ruling, civil servant class to the district. The aim of the study is to examine the transformations that occurred in Beşiktaş district at this period by the cause-effect relationship. The changes in the general landscape of Istanbul and

\footnotetext{
${ }^{1}$ Dr. Öğr. Üyesi, Mardin Artuklu Üniversitesi, Mühendislik Mimarlık Fakültesi, Mimarlık Bölümü, muratcaglayan@artuklu.edu.tr, ORCID: Orcid.org/0000-0001-7273-4888.
}

Geliş/Received: 20.03.2020, Kabul/Accepted: 04.07.2020 
Beşiktaş have experienced rapid transformations with the court case. In this century, a cyclical process that affects urban transformations, architecture, and therefore social structure and economic situation can be defined. In other words, the economic power and social life of the rich people who came to Beşiktaş with the palace were reflected in architecture, urban and social fabric.

Keywords: Architecture, Nineteenth Century, Ottomon, Beşiktaş, Urban Transformation.

\section{GíRIŞ}

Beşiktaş, İstanbul'un Avrupa kıtasında yer alan ilçelerinden biridir. Doğusunda İstanbul Boğazı, kuzeyinde Sarıyer ilçesi, batısında Şişli ilçesi, güneyinde Beyoğlu ilçesi ile çevrelenmiştir. Yazıya konu olan ondokuzuncu yüzyıl Beşiktaş’ındaki kentsel dönüşümü incelemek için ise bir sınır çizilerek konu ele alınmıştır. Çalışma alanı; Beşiktaş’ın ilk yerleşimi olan köyiçi ve sahili, onsekizinci yüzyılda sırtlara doğru yerleșimin arttı̆̆ı Abbasağa'yı, farklı bir konut tipi olarak ondokuzuncu yüzyılda ortaya çıkan Akaretler'den ve Yıldız Sarayı yerleşkesini de içeren Serencebey'i içine alır (Şekil 1). Beşiktaş'ın ondokuzuncu yüzyılına gelmeden önce ise cumhuriyet dönemi ve ondokuzuncu yüzyıl öncesi Beşiktaş’taki önemli tarihi olaylara değinilmiştir.

Şekil 1: Çalışma alanı ve mahalle sınırları (Url 1 kaynă̆ındaki haritalardan düzenlenmiştir).

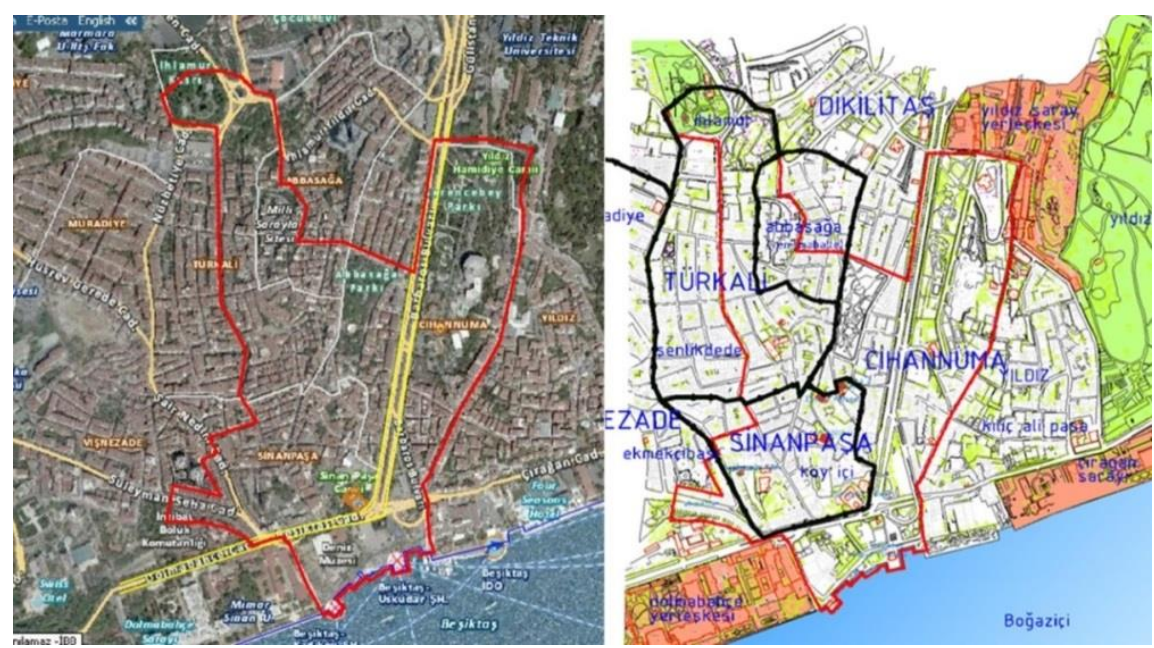

\section{Cumhuriyetten Günümüze Beşiktaş'ın Tarihsel Gelişimi}

Türkiye Cumhuriyeti ilan edildiğinde Beşiktaş, kentin Beyoğlu ilçesinin bir parçasıdır ve yönetim olarak Beyoğlu Mutasarrıflığı'na bağlıdır. 1930'da Beyoğlu'ndan ayrılıp yeni bir ilçe halini almıştır. Cumhuriyetin ilk onbeş yılı boyunca, kentsel gelişmede ağırlığın başkent Ankara'da ve İzmir gibi maddi yönden de yıkıma uğramış kentlerde olması, İstanbul ve önemli bir semt olan Beşiktaş'1 etkilemiş, bu ilçede hemen hemen hiçbir imar faaliyetinde bulunulmamıştır. 3 Mart 1924'te hilafetin kaldırılması ve Osmanlı hanedanı mensuplarının yurt dişına çıkartılmalarıyla saraylar ve Beşiktaş'tan Arnavutköy'e kadar kıyı boyunca sıralanan yalılar boşalmış, bunların bazıları kamu kurumlarına verilmiş, bir kısmı depo ve okul olarak kullanılmaya başlamış, bazıları da yıkılmıştır. Konaklar da benzer akibete uğramış, konak düzeninin çökmesiyle birlikte kimi bölünüp kiraya verilmiş, kimi terk edilmiş, kimi de yanmış ya da yıkılmıştır. Bu dönemde Beşiktaş'taki ticari hayat da sarsıntı geçirmiştir. Cumhuriyetin erken döneminde Beşiktaş, İstanbul'un kır-kent iç içeliğini sürdüren bir semt olmaya devam etmiştir ve mahalle aralarının iç kısımlarını bostanlar, Ihlamur'un ötesini de çiçek bahçeleri ve dutluklar kaplamaktadır (Akbayar, 1998: 17). 
Beşiktaş'ın görünümünü değiştiren ilk girişimler, Lütfi Kırdar'ın belediye başkanlığ döneminde (1938-1949) başlamıştır. Lütfi Kırdar, Fransız şehir plancısı H. Prost'a hazırlatılan ve 1939'da onaylanan nâzım plan doğrultusunda kentte geniş çaplı bir imar hareketine girişmiştir. Kendisi bulvarlar açmak, meydanlar oluşturmak, mevcut yolları genişletmek ve iyileştirmek, yeşil alanları düzenlemek, rekreasyon alanları yaratmak, su, elektrik, ulaşım gibi temel belediye hizmetlerinde artışlar sağlamak ve kente Cumhuriyetin simgesi olacak anıtsal yapılar kazandırmak şeklinde özetlenebilecek temel ilkeler doğrultusunda birçok girişimde bulunmuştur. Bu dönemde, Dolmabahçe'den Rumelihisarı'na uzanan ve ilçeyi kente bağlayan ana yol ile Zincirlikuyu-Beşiktaş yolu ve semtin iç kesimlerini ana yola bağlayan Ihlamurdere Caddesi'nin niteliği yükseltilmiştir. Beşiktaş İskelesi'nin arkasında bulunan sokaklar istimlâk edilerek Barbaros Meydanı açılmış, önündeki duvar kaldırılarak Barbaros Hayrettin Paşa Türbesi ortaya çıkartılmış, meydanın kenarına da Barbaros Anıtı yaptırılmıştır. Beşiktaş Muhafızı Yedi-Sekiz Hasan Paşa’nın türbesi kaldırılarak Yahya Efendi Türbesi'ne nakledilmiştir (Şekil 2). Lütfi Kırdar'ın ağzından yazılan "Yenileşen Ístanbul" adlı kitapta bu alanla ilgili şunlar aktarılmıştır:

"Barbaros'un yattığ yerin etrafinı kaplayan çirkin salaşlarl, odun ve saman depolarını, bu Türk Amirali ile hiç münasebeti olmadığı halde, onun güzel türbesi yanına gömülerek üstüne çirkin türbe yapılan Beşiktaş Muhafızı Hasan Paşa'nın mezarını kaldıran ve nihayet Barbaros'a bir abide diken Cumhuriyet rejimi olmuştur. ”(K1rdar, 1947: 65).

Şekil 2: Prost Planı kararlarında Barbaros Meydanı için yapılan yıkımlar (Gökyay, 2009: 191).

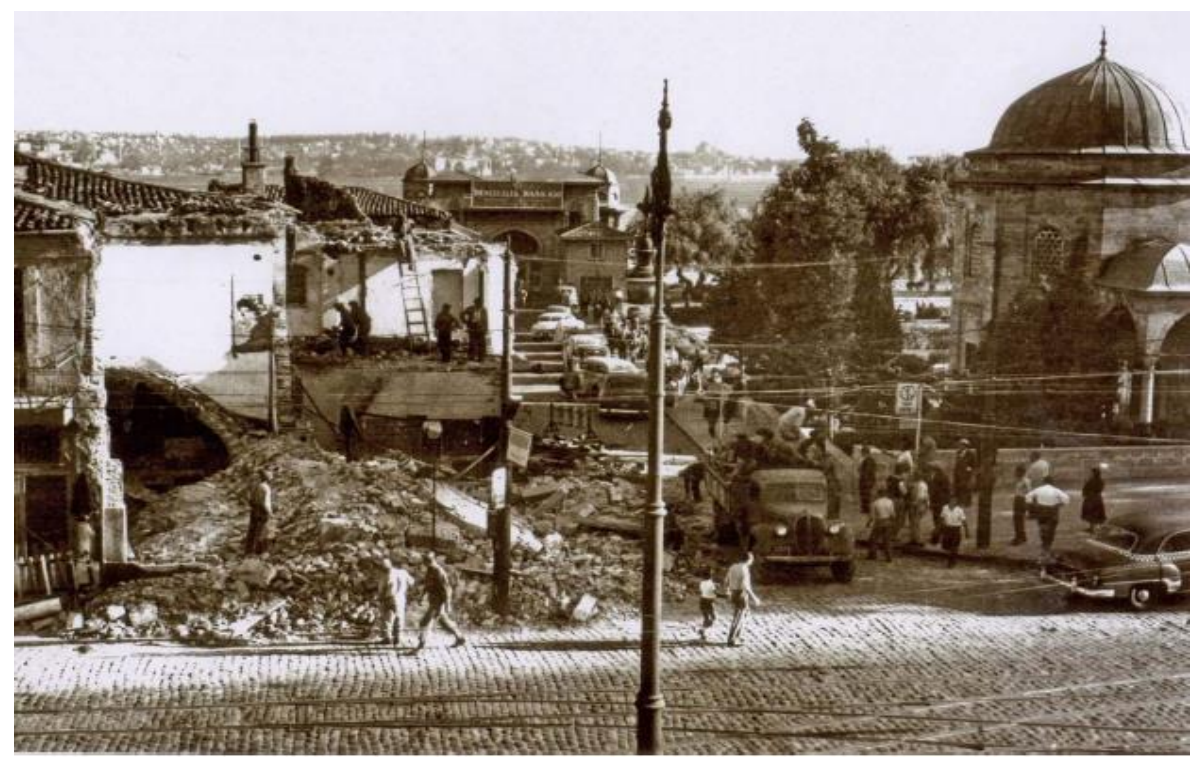

Hükümetçe verilen bir karar üzerine Belediye tarafından pek çok dükkân istimlâk edilmiş, bu sırada türbenin, Sinanpaşa Camii’ne bakan tarafındaki, avlu duvarına bitişik olan Hacı Ahmet Ağa Çeşmesi ortadan kaldırılmıştır. Beşiktaş’’ı derinden etkileyen ve kentsel dokusunu değiştiren ikinci imar hareketi, 1950'de iktidara gelen Demokrat Parti döneminde başlamıştır. Bu dönemde nüfus ve iç göç artmış, İstanbul da bu durumdan en çok nasibini alan yer olmuştur. Kent bir sanayi, ticaret ve turizm merkezi olarak yeniden biçimlenmiş, kent içinde ve çevresindeki yollar genişletilmiş, bulvarlar açılmıştır. Bu durum, tarihi bir kentte yapılmaması gereken, kentsel doku üzerinde büyük yaralar açan, bir değişim olmuştur (Şekil 3). 
Şekil 3: 1944 ve 1966 hava fotoğraflarında çalışma alanı ve açılan Barbaros Bulvarı görüntüsü (Url 1 kaynă̆ından düzenlenmiştir).

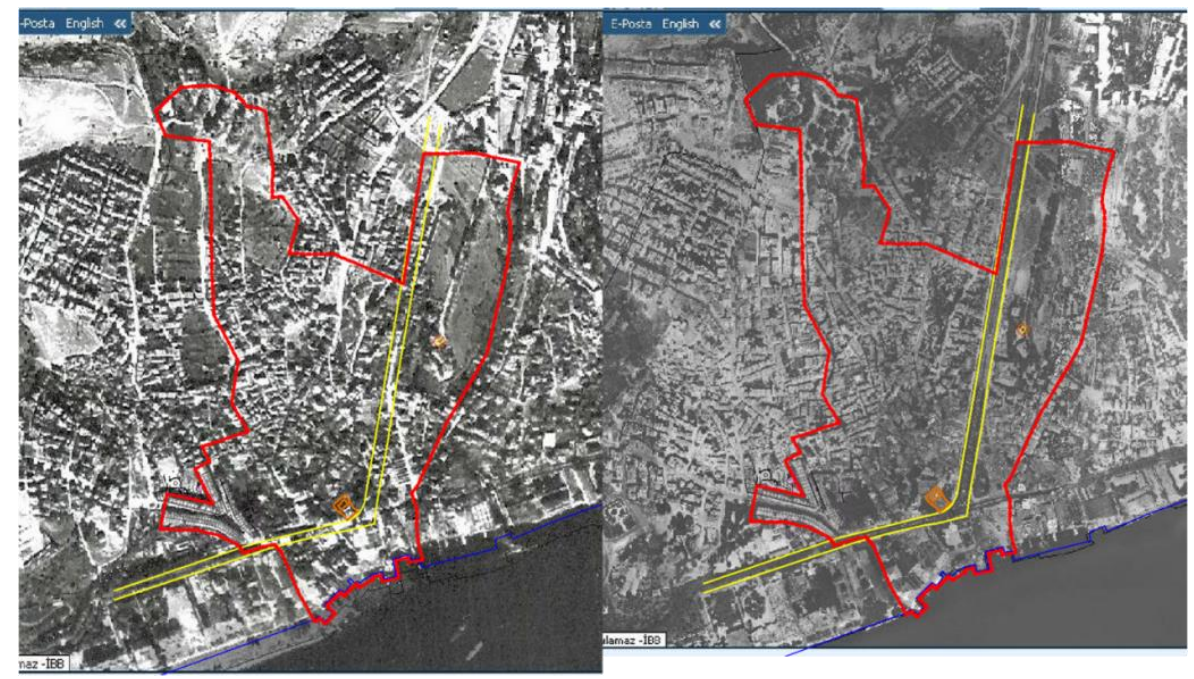

Beşiktaş’ın bugün 22 mahallesi vardır ve ilçenin çekirdeğini oluşturan Beşiktaş, Ortaköy, Kuruçeşme, Arnavutköy, Bebek gibi tarihsel semtler dışındaki yerleşim yerleri son kırk yıl içinde ortaya çıkmışlardır. Büyük ölçüde kırsal alanların iskâna açılmasıyla başlayan Cumhuriyet dönemindeki gelişim sürecinin en önemli adımı, 1950'de tarihi Levent Çiftliği arazisi üzerinde bahçeli evler düzeninde bir toplu konut uygulaması olarak Levent mahallesinin kurulmasıla atılmıştır. Onu ikinci, üçüncü, dördüncü Levent denilen yeni yerleşimler izlemiştir. Son otuz yılda da Konaklar, Akat, Etiler, Nisbetiye, Levazım ve Kültür mahalleleri oluşmuştur (Akbayar, 1998: 20).

1956 yılında Dolmabahçe Caddesi genişletilmiş, 1956-1958 yılları arasında, yerleşimi bıçakla ikiye bölen ve mevcut dokuyu hiç dikkate almayan, Beşiktaş'1 Zincirlikuyu'ya bağlayan Barbaros Bulvarı açılmış ve böylece semt birçok kültür varlığını kaybetmiştir (Şekil 4). 1960'ların ortalarına kadar ahşap dokusunu ve bostanlarını koruyan Beşiktaş merkezi bu tarihten itibaren apartmanlaşmaya başlamıştır.

Şekil 4: Beşiktaş- Levent aksını bağlayan Barbaros Bulvarı yapılırken (Beşiktaş Kaymakamlı̆̆l Arşivi-1956).

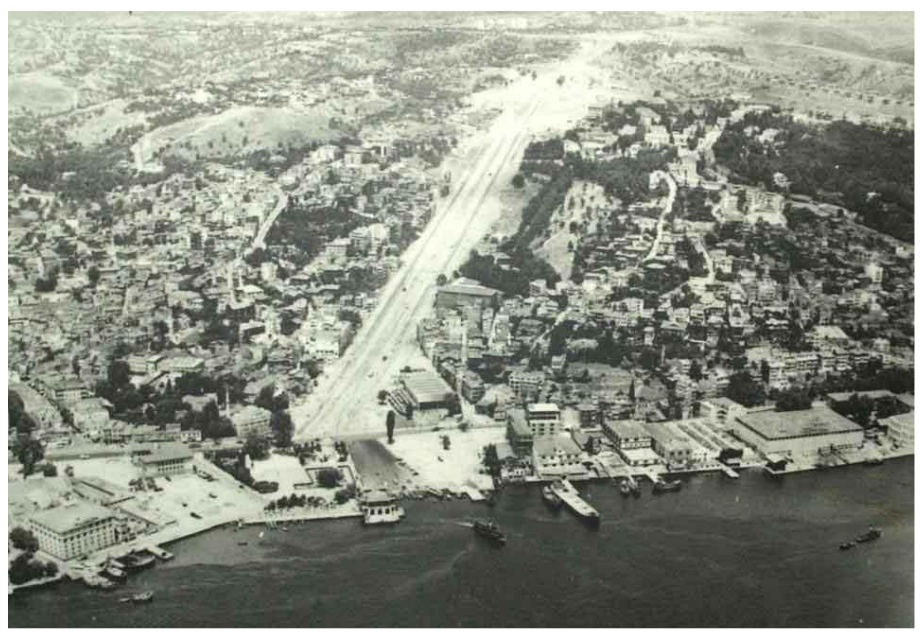


1973’te açılan Boğaziçi Köprüsü, semtin içine giren çevre yoluyla Beşiktaş’1 trafik sorunu ile karşılaştırmış ancak ulaşım kolaylığı açısından da talebi arttırmıştır. 1980'lerdeki yeni iktidarın İstanbul'u bir iş ve finans merkezi yapma amacı doğrultusundaki girişimleri Beşiktaş'ta derin izler bırakmıştır. Bedrettin Dalan'ın Belediye başkanlığı döneminde Dolmabahçe Sarayı ile Yıldız Sarayı'nın yeşil alanına iki büyük otel (Swiss ve Conrad) yapılmış. 19 Ocak 1910'da elektrik tesisatı yüzünden çıkan yangınla büyük tahribata uğrayan Çırağan Sarayı, restore edilip otel haline getirilmiş, dönemin "Şeref Stadı" olarak da bilinen bahçesine yeni bir otel (Kempinski) inşa edilmiştir (Gökyay, 2000: 18).

Ayrıca Zincirlikuyu-Levent arasına da yüksek irtifalı iş merkezleri izni verilmiş, bu dönemden itibaren bu alan, hızla gökdelen biçimindeki konut, alışveriş ve iş merkezleriyle donatılmıştır. Bu gelişmeler zaten yoğun olan trafiği daha da arttırmış, barındırdığı çok sayıdaki işyeriyle Beşiktaş, ticari ve finansal merkez olmaya başlamıştır.

\section{Ondokuzuncu Yüzyıla Kadar Beşiktaş’ın Tarihsel Gelişimi}

Beşiktaş’ın eski ve yeni sakinleri arasında yaygın olan ve yazılı kaynaklara da geçmiş bulunan teze göre, Türklerce verilen Beşiktaş adının kökeni; "Beştaş” tan, bu da Barbaros Hayrettin Paşa'nın gemilerini bağlamak için kıyıya diktirttiği beş taş sütundan gelmektedir. Beştaş adı zamanla Beşiktaş'a dönüşmüştür (Ayvansarayi ve diğerleri, 2001: 493).

Beşiktaş'ın Osmanlı öncesi dönemdeki adına ilişkin diğer bir kayıt ise Evliya Çelebi’nin seyahatnamesinde yer almaktadır. Onun anlatımıyla;

"Zamanı kadimde bu şehir kefere destinde iken ismine Konapetro derlerdi, yani taş beşik demektir. Sebebi oldur kim bu şehir zemini çengelistan-ı hıyâbân iken Yaşka namında bir ruhban rahib bunda bir kenise-i azim bina edip Kudüs-i Şerif'de Hazret-i İsa'nın rahm-i maderden müştak olduğu taş tekneyi mezkûr ruhban Kudüs'den getirip bu Beşiktaş'daki deyrine koyduğundan lisan-ı Rum'da Beşiktaş ismiyle bu şehir şöhret bulup ma'mur abadan olup ba'dehu ruhban mürd oldukda taş beşiği Herkioğlu İlya nam kral ol beşiği Ayasofya deyrinin sağ tarafindaki tabakaya koyup hala ziyaretgâhtır. Hala anınçün lisan-ı Müslimde bu şehre Beşiktaş derler." (Evliya Çelebi, 1998: 209)

Evliya Çelebi’nin bu anlatımı, Banoğlu (2008: 151-153) tarafından "Tarihi ve Efsaneleriyle İstanbul Semtleri” adlı kitapta açıklanmıştır: Yaşka adında bir rahip burada büyük bir kilise yaptırmış, Kudüs'ten de Hz. İsa'nın içinde yıkanmış olduğu beşiği, Beytülharem'den getirip bu kiliseye koymuştur. Rahip öldükten sonra kral beşiği Ayasofya'ya getirmiştir ve Beşiktaş adı, bu taş beşikten gelmektedir. Ayrıca bu kitapta başka bir rivayete daha değinilmiş, Beşiktaş adının çifte sütunların üzerinde bulunan beşik resimlerinden geldiği aktarılmıştır (Şekil 5).

Şekil 5: Onbeşinci yüzyılda Buondelmonti'nin İstanbul resminde Galata surları dışında să̆ üstte görünen diplokionion (çifte sütun) (Eyice, 1976).

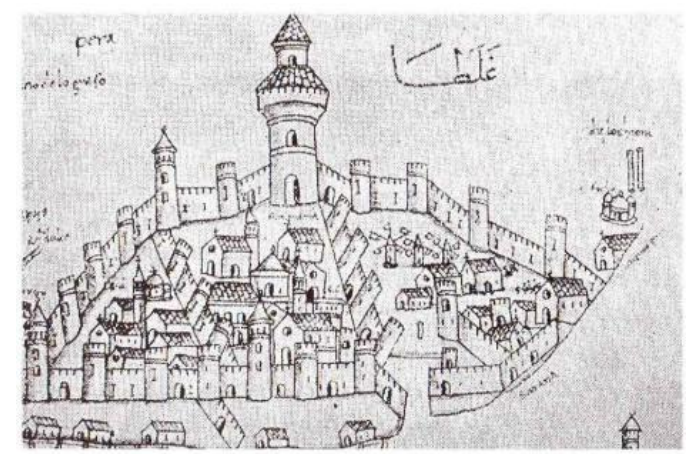


Beşiktaş bir yerleşim yeri kimliğini Osmanlı döneminde kazanmıştır. Bizans'ın son döneminde (1261-1453) Köyiçi'nde ve Ortaköy'de sürekli yerleşmeler olduğuna ilişkin izler varsa da bunların niteliği ve boyutları belirsizdir. Beşiktaş'ın coğrafi konumu bakımından Tarihi Yarımada’ya ve Haliç'in karşı kıyısındaki Galata'ya yakınlığı, gelişmesi için bir avantaj gibi görünse de bütün İlkçağ ve Orta çağ yerleşmelerinin temel unsuru olan güvenlikten yoksun olması böyle bir büyümeyi olanaksız kılmıştır. Bizans dönemi boyunca Boğaziçi özellikle Karadeniz'den gelen yağmacıların akınlarına uğramış, bunların yarattığı tahribat ve korku, sur dışı yerleşmelerin gelişmesini engellemiştir. Beşiktaş'ın Osmanlı döneminde bir yerleşim yeri kimliği kazanması Karadeniz'in geniş ölçüde Osmanlı Devleti'nin denetimi altına girmesi sayesinde olmuştur. Boğaziçi'nde yerleşmeyi etkileyen bir başka unsur da iklim koşullarıdır. Özellikle kıyı kesiminin sert hava akımlarına açık oluşu ve denizin yarattığı nem kıyı boyu yapılarının çok korunaklı olmasını gerektirmekte, bu da gelişmiş ve pahalı inşaat anlamına gelmektedir. Osmanlılar ise ucuzluğu, kolay yapılması ve kolay yenilenebilmesi gibi nedenlerle daha çok ahşap yapıları tercih etmişlerdir. Bu tür yapıların kıyılarda ancak yazlık yerleşmeye elvermesi Boğaziçi'nin yirminci yüzyıla kadar uzanan tarihi boyunca yalı denen özgün bir mimari türün ortaya çıkmasına yol açmıştır. Asıl yerleşmeler ise sert hava alanlarından daha az etkilenen koylarda, vadilerde, tepelerin güneye bakan yamaçlarında olmuştur. Beşiktaş'ın gelişmesi de bu doğrultuda olmuştur (Akbayar, 1998: 21).

Fetihten sonra Fatih Sultan Mehmed'in iskân siyasetiyle İstanbul'da nüfus hızla artmaya başlamıştır. Galata'nın topografik yapısı ve bir ticaret kolonisi olma özelliği, Müslümanları yeni yerleşmeler için Haliç'in kuzey kıyılarına ve Boğaziçi'ne doğru yöneltmiştir. Beşiktaş, Boğaziçi kıyılarında gelişen ilk Osmanlı yerleşmesi olmuştur. Kıyı kesimi, Sultan II. Bayezid döneminde (1481-1512) kaptan-1 deryâlara verilmiş ve kaptan-1 deryâlar için bir yalı yaptırılmıştır (Akbayar, 1998: 21). Bu tarihlerde bugünkü Dolmabahçe'nin yerinde bulunan koy, doldurulmuştur. Koyun doldurulması ile ilgili olarak yazılı kaynaklarda farklı tarihler görülmekte olup çoğunlukla 16. yüzyıl işaret edilmiştir. Ayrıca bu civarda 16. yüzyıl başlarında yaşamış ve "tekerlek" lakabı ile şöhret bulmuş olan Mustafa Efendi bir mescit yaptırmıştır (Göyünç, 1948: 7).

Beşiktaş kıyısı onaltıncı yüzyılda denizcilikle iç içe olma özelliğini sürdürmüş, Barbaros Hayrettin Paşa, Sinan Paşa ve Kılıç Ali Paşa gibi kaptan-ı deryâlar Beşiktaş'ta kalıcı izler bırakmıştır (Akbayar, 1998: 22). Sultan I. Ahmed döneminden (1603-1617) başlayarak Beşiktaş kıyıları hanedana geçmiş ve has bahçeler olarak düzenlenip sahil sarayları yaptırılmıştır. Onaltıncı yüzyılda Osmanlı hanedanının Beşiktaşa ilk eseri olarak, Kanuni Sultan Süleyman tarafından Beşiktaş Bahçesi arkasındaki tepede bir yazlık saray yaptırmıştır (Göyünç, 1948: 8). Süleyman Sarayı olarak anılan bu yapının daha sonra inşa edilen Bayıldım Kasrı'nın yerinde olduğu tahmin edilmektedir. Beşiktaş İskelesi'nin ardındaki meydan 16. yüzyıldan başlayarak Rumeli-Anadolu arasında işleyen kervanların durağı, aynı zamanda Anadolu'dan gelip Rumeli'den seferlere katılan eyalet askerlerinin geçit yeri olmuştur (Akbayar, 1998: 22).

Onaltıncı yüzyılda Beşiktaş'ın toplumsal yaşamında iz bırakan iki önemli kişi "Deli Birader" namıyla anılan Gazalî Mehmed Efendi ile Yahya Efendi'dir (Akbayar, 1998). Gazali, 1525 yılında, Beşiktaş'ta bir mescit, bir medrese, bir zaviye, bir bahçe, bir de kaplıca tarzında bir hamam yaptırmıştır. Zaviyenin, bugünkü Neccarzade Türbesi'nin yerinde olduğu bilinmektedir (Göyünç, 1948: 9). Yahya Efendi ise bugünkü Çırağan Sarayı'nın arkasındaki tepenin yamacında kurduğu tekke ile İstanbul'un en ünlü mutasavvıfları arasında yer almıştır (Akbayar, 1998: 24).

Onyedinci yüzyılda Beşiktaş'ın çehresinin hayli değişmeye başladığı görülmektedir. Dolmabahçe Koyu genişletilmiş ve yapılaşma başlamıştır. Beşiktaş Sarayı'nın ilk yapıları inşa edilmiştir ve bu dönemden başlayarak üç yüz yıllık bir süreçte Beşiktaş kıyıları, hanedan üyelerine ait bir biri ardınca yapılan, yenilenen onlarca sarayla donatılmıştır. Yazlık saraylara ilkbaharda yayımlanan göç fermanıyla taşınılır; sonbahardaki fermanla da kışlık saraylara geri dönülür. Hanedanın Beşiktaş'la ilişkisi sonucu, sarayla ilişkili kişilerin ve Osmanlı üst tabakasında seçkin bir 
yeri olan ilmiye sınıfı mensuplarının da Beşiktaş'ta ikamet etmeye başladığı görülmektedir (Akbayar, 1998: 24).

Onyedinci yüzyılın ikinci yarısındaki Beşiktaş'ı anlatırken Evliya Çelebi semtin "ayân ve kibar" insanlarla dolu olduğundan söz etmekte, ayrıca halkın çoğunun Anadolu kökenli olduğunu ve bağcılıkla uğraştığını belirtmekte ve bahçelerinin de güzel olduğunu eklemektedir. Yapılar ile ilgili ise, "alçak bayırlar üzerinde kat kat bağlı, bahçeli, altıbin kadar yalı ve ev"lerin bulunduğundan bahsetmektedir. Ayrıca, kasabanın yetmiş kadar dükkânı, çeşmesi ve sebilleri olduğunu, her evde ve bostanda tatlı su kuyuları bulunduğunu belirtmiştir (Göyünç, 1948: 30).

Hanedanın Beşiktaş'a ilgisinin diğer bir sonucu da buradaki sarayların koruyuculuğunu üstlenen bir Bostancı garnizonunun kurulmuş olmasıdır. Beşiktaş, 17. yüzyılda Abbasağa ve Vişnezâde mahallelerinin oluşumuyla sırtlara doğru genişlemesini sürdürmüştür. Semtin ticari merkezi durumundaki Köyiçi'nde Müslümanlar, Rumlar, Ermeniler birlikte yaşarken Abbasağa sırtlarına doğru Ermeniler, Uzuncaova'ya doğru da Rumlar yerleşmişlerdir. Az sayıda da Yahudi vardır. Kır-kent iç içeliğinin sur içinden daha yoğun olduğu Beşiktaş 18. yüzyılda da bu özelliğini sürdürmüştür. Ancak Sultan III. Ahmed döneminde, özellikle Lâle Devri'nde (1718-1730) İstanbul'da yaşanan toplumsal değişimin iki ünlü mekânından birisi de Beşiktaş olmuştur (Şekil 6) (Akbayar, 1998: 25).

Şekil 6: D'ohsson'un Tableau General De L'Empire Ottoman adlı kitabında yer alana bir gravürde 18. yüzyılda Beşiktaş Sahil Sarayı ve sırtlarındaki yerleşim (Akbayar, 1998: 25).

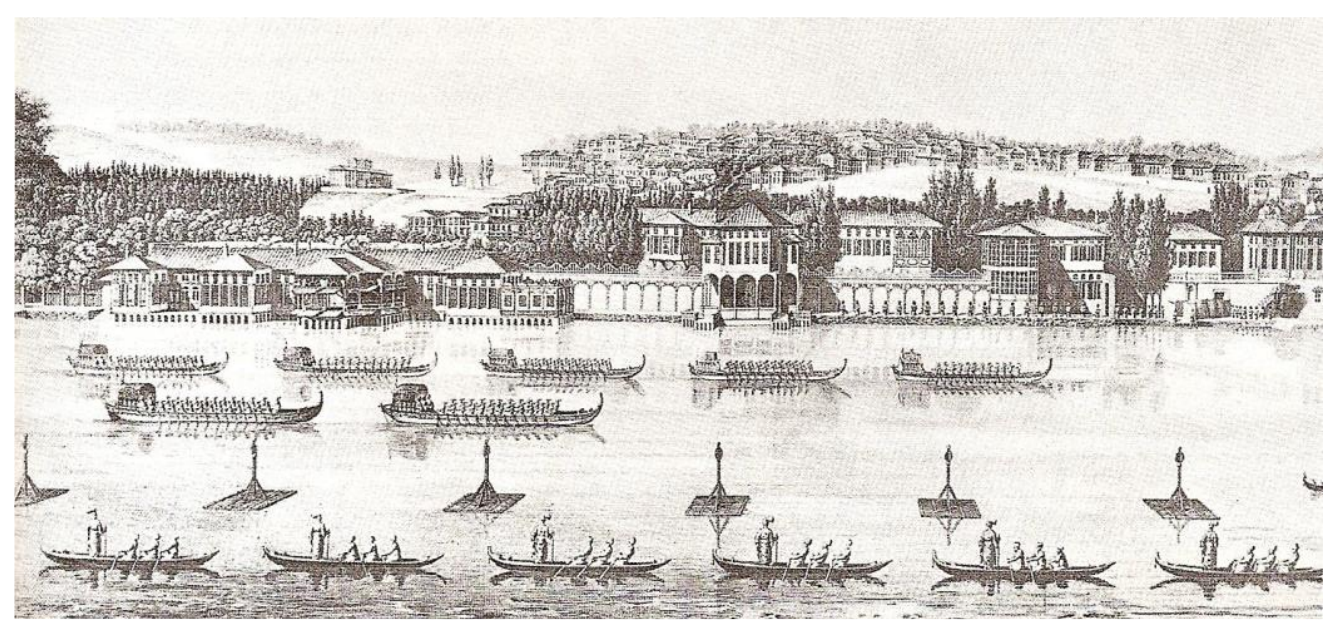

Lale Devri'nin 1730'daki kanlı Patrona Ayaklanması ile son bulmasının ardından, Sultan I. Mahmud haraplaşan Beşiktaş Sarayı'nın yapılarını onartmış, Sultan III. Mustafa 22 Mayıs 1766'daki büyük depremde hayli tahribata uğrayan Beşiktaş Sarayı'nı yeniden tadil edip ve yazlık saray olarak kullanmayı sürdürmüştür. Sultan I. Abdülhamid, 1761'de yeniden bir sahilhane ile kasır, 1782'de iki kasır ve büyük bir havuz yaptırmış, 1783'de sarayın ahşap kısımları yıktırılarak yerlerine kargir binalar inşa edilmiştir. Bu durum Beşiktaş'ın önemini arttırmış, birçok yalı ve iskeleler inşa edilmiştir (Göyünç, 1948: 32). Onsekizinci yüzyılda Beşiktaş yerleşimini bir yandan Beşiktaş Deresi ile Ihlamur Deresi vadisi boyunca genişletirken, öte yandan Serencebey sırtları da iskâna açılmaya başlamıştır (Şekil 7) (Akbayar, 1998: 24). 
Şekil 7: Ondokuzuncu yüzyıla kadar Beşiktaş mahallelerinin gelişimi.
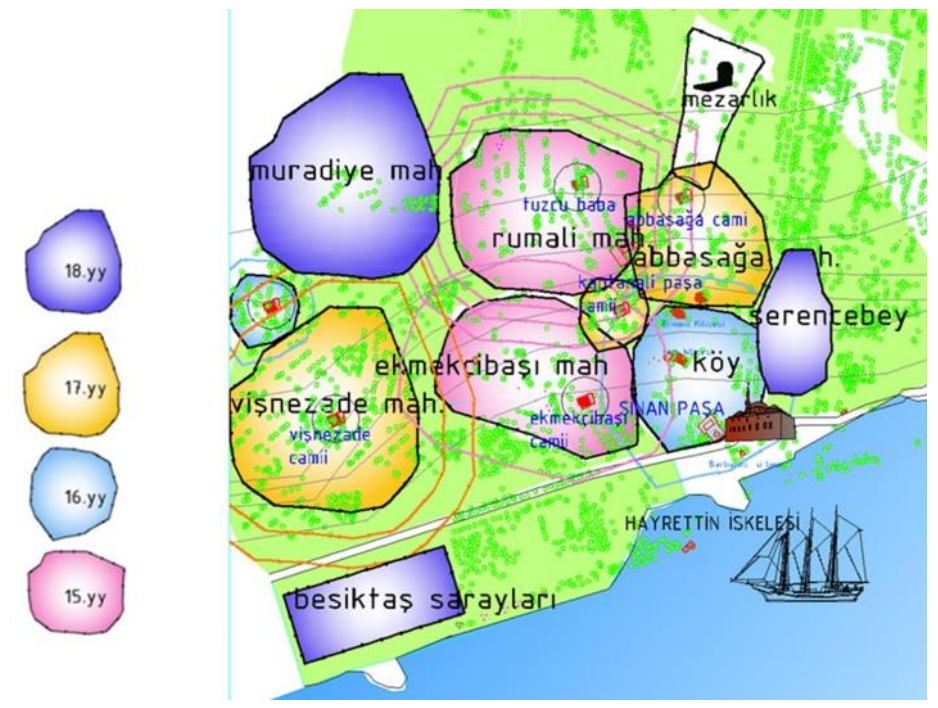

\section{Ondokuzuncu Yüzyılda Beşiktaş}

Sultan II. Mahmud'un Topkapı Sarayı'nı bırakarak kış aylarını da Beşiktaş Sarayı'nda geçirmek istemesi başlangıçta yöneticilerin tepkisiyle karşılaşmış ancak 1820'den sonra çoğu zaman Beşiktaş ve Çırağan sarayları ile Yıldız Kasrı'nda kalmış, 1834'de Beşiktaş Sarayı yenilendikten sonra bütünüyle Topkapı Sarayı'nı terk etmiştir. Padişahla birlikte hanedanın diğer üyeleri ve devlet ricali de Beşiktaş'a yerleşmeye başlamışlardır (Akbayar, 1998: 25).

Bu asrın ilk çeyreğinde (1811-1821) Beşiktaş sahilinde Çırağan ve Beşiktaş sahil sarayları arasında bir kısmı devletin üst makamlarında bulunan kişilere, bir kısmı serbest meslek erbabına ait olmak üzere pek çok yalının bulunduğu, bostancıbaşı defterlerinden anlaşılmaktadır (Göyünç, 1948: 32). Bu defterlere göre, Dolmabahçe ile Beşiktaş arasında çok sayıda yalının yanı sıra, Dolmabahçe İskelesi, Emlaki hümayun bostan, Beşiktaş Sahilsarayı Hümayunu, Hayrettin Medresesi ve Camii Şerifi, iskele, Süleyman kahvesi, Hasoda bekçisi Hasan'ın kahvesi, Beşiktaş İskelesi, Hayrettin Paşa Türbesi sıralanmaktadır (Gökyay, 2000: 15). Sahilde yalılardan başka yer yer kahvehanelere ve Beşiktaş İskelesi'nin bulunduğu meydanda marangoz ve kalafatçı dükkânlarına rastlanmakta, bu meydanın iş muhiti olması dolayısıyla en işlek yer olabileceği anlaşılmaktadır (Göyünç, 1948: 32).

1854'de modern kent yönetimine doğru önemli bir adım olan Şehremaneti kurulmuştur. 1868'de "Dersaadet İdare-i Belediye Nizamnamesi"nin yayımlanması, 1877'de "Dersaadet Belediye Kanunu"nun kabulü, 1848, 1849 ve 1864 tarihli Ebniye nizamnameleri ile 1882 tarihli "Ebniye Kanunu" kentin yeni bir çehre kazanmasına katkıda bulunmuş ve sarayın yakın çevresini oluşturması bakımından Beşiktaş'taki etkileri daha kalıcı olmuştur. 1857'de Beşiktaş rihtımı tamamen yenilenmiş, 1864 'te Dolmabahçe rıhtımı yapılmış, 1870 'den başlayarak saraylara ve kasırlara ulaşan yollar genişletilmiş, Mazhar Paşa'nın şehreminliği döneminde (1880-1890) Dolmabahçe-Ortaköy arasındaki ana yol ağaçlandırılmış, 1877 tarihli Dersaadet Belediye Kanunu ile Beşiktaş-Ortaköy arasında ahşap yapı inşası yasaklanmıştır (Gökyay, 2000: 15).

Ondokuzuncu yüzyılın sonlarına doğru sahil kısmındaki yalıların birçoğu ortadan kalkmıştır. Bunun nedeni yangınlar, yapıların satılııı̧ olması veya miras yolu ile varislere geçip, sonrasında sahipsiz ve bakımsız kalmasıdır (Göyünç, 1948: 40). 1853-1854 yıllarında Beşiktaş Sahil Sarayı tamamen yıktırılarak yerine Dolmabahçe Sarayı ve karşısına has ahırlar inşa edilmiştir. Asrın ikinci yarısında, Sultan II. Abdülhamid'in sürekli olarak Yıldız'da kalmasından sonra, Beşiktaş'ta pek çok imar faaliyetinde bulunulmuştur. Mevcut camiler tamir edilmiş, yıkılmış olanlar yeniden yapılmışıır 


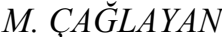

(Göyünç, 1948: 40). II. Abdülhamid döneminde 1878'den başlayarak, Yıldız Sarayı'nın yalnız padişahın ikametgâhı değil, yönetiminin merkezi olması Beşiktaş'ı türlü yönlerden etkilemiştir. Öncelikle padişahın yakın çevresinde yer alanlar ikametgâhlarını Yıldız Sarayı'nın yakınlarına taşımışlardır. Ayrıca saray yakınlarında Orhaniye Kışlası ve Ertuğrul Kışlası ile İstanbul tarihinde iz bırakmış bir kişi olan Beşiktaş Muhafızı Yedi-Sekiz Hasan Paşa'nın yönettiği karakol binaları inşa edilmiştir. 1894'teki İstanbul depremi Beşiktaş'ta da tahribata neden olmuş, Sinanpaşa Camisi ile Beşiktaş İskelesi Camisi'nin minareleri yıkılmış, Beşiktaş Merkez Karakolu'nun çatısı çökmüş, duvarları çatlamış, Beşiktaş Merkez Rüşdiyesi'nin de duvarları çatlamış, sıvaları dökülmüş ve camları kırılmıştır (Akbayar, 1998: 26).

Ondokuzuncu yüzyılda ilçe önemli bir kültürel oluşuma da ev sahipliği etmiş, Beşiktaş ve Ortaköy'de oturan bir grup aydının 1815 sonlarından başlayarak düzenli biçimde bir araya gelmeleriyle oluşan bu harekete "Beşiktaş Cemiyet-i İlmiyesi" denmiştir. Tarih, din, felsefe, pozitif bilimler ve edebiyat alanında düşünce alışverişinde bulunmayı, ayrıca öğrenci yetiştirmeyi de amaçlayan bu topluluk, 1826'da Yeniçeri Ocağı'nın kaldırıldığı ortamda Bektaşilik ve dinsizlikle suçlanarak dağılmak zorunda kalmış, üyelerinin bir bölümü de sürgüne gönderilmiş̧ir. Osmanlı tarihinin son dönemi sayılan II. Meşrutiyet (1908-1918) ve Mütareke (1918-1922) yılları tüm ülkede olduğu gibi Beşiktaş'ta da olaylı geçmiştir. II. Meşrutiyet'in ilanı, 1909'da yaşanan 31 Mart Ayaklanması'nın ardından Sultan II. Abdülhamid'in Yıldız Sarayı'nda tahtından indirilip sürgüne gönderilmesiyle yönetim merkezi olma niteliğini, özel konumunu yitirmiştir (Akbayar, 1998: 28).

\section{Ondokuzuncu yüzyılda Beşiktaş’taki dönüşümler}

Ondokuzuncu yüzyılda Beşiktaş’taki kentsel dönüşümün tetikleyici, hızlandırıcı etkenlerinin başında, yangınlar ve saray erkânının ikameti vardır. Ondokuzuncu yüzyıldaki İstanbul yangınları afet olarak Osmanlı İdaresinde de birçok nizamnamenin yapılmasına sebebiyet vermiştir. 1848'te Meclis-i Mahsus'ta yangın sorununa ilişkin toplantılar yapılmış ve sonunda bu konuda alınması gereken önlemler ve imar konusuna yönelik birtakım kararlar belirlenmiştir (Özyurt, 2007).

Alınan kararlarda kâgir yapı yapma şartı, kâgir yapmaya gücü yetmeyenlerin de iki ahşap bina arasında kâgir yangın duvarı yapma şartları, yangınların önüne geçememiştir. Bu sebeple, tek yapı ölçeğinde alınan bu kararlardan kentsel ölçekli yeni kararlara adım atılmıştır. Bu durum, kentsel dönüşümün başlangıcı olmuştur. Kentsel ölçekte alınan kararlarda, dar yolların genişletilmesi alınan en önemli kararlardandır. Ancak mevcut dokuda böyle bir çalışmaya gidilmesi pek de kolay olmayacaktır. Bu bağlamda yangınlar sonrası yanan ahşap evler, dokuda boşalmayı sağlamıştır. Belirli kabullerle tüm yapı adası boş kabul edilerek 'tarla kuralı' ile yeni yol ve parsel hizaları belirlenmiş̧tir.

Kuşkusuz, bu değişimler ondokuzuncu yüzyıl Beşiktaş'ında da yaşanmıştır. Ancak Beşiktaş'ın topoğrafyası düşünüldüğü zaman aslında tarla kuralı ile gelen ızgara plan sistemini uygulamak zor olmuştur. Aynı zamanda yangınların kısmi alanlarda yaşanması, yangınlar sonrası düzenlemeler neticesinde doku bütününün yamalı bir şekilde görülmesine sebep olmuştur.

Aşağıdaki çizelgede çalışma alanı içinde görülen yangınlar ve kayıplar listelenmiştir. Kayıplara bakıldığında yanan bina sayısı, bir yapı adasının çoğunluğunun yok olduğu varsayımına ulaştırabilecek değerdedir. 1922 Pervitch Haritalarına bakıldığı zaman da bir yapı adasındaki haneler sayıldığında bu varsayım bir ölçüde doğru kabul edilebilir. ${ }^{2}$

\footnotetext{
${ }^{2}$ Ekler bölümünde ondokuzuncu yüzyıldan ve yirminci yüzyıl başlarına kadar Beşiktaş için hazırlanmış haritalara bakınız.
} 
Tablo 1: Onsekizinci yüzyıldan Cumhuriyet'e kadar Beşiktaş Köyiçi’nde kayda geçmiş olan yanginlar (Gökyay, 2009: 16).

\begin{tabular}{|l|l|l|l|}
\hline Yer & Tarih & Yanan & Kaynak \\
\hline $\begin{array}{l}\text { Beşiktaş Yusuf } \\
\text { Efendizade Yalısı }\end{array}$ & 3 Eylül 1754 & 1 bina & (Cezar, 2002) \\
\hline $\begin{array}{l}\text { Beşiktaş İkelesi Veli Ağa } \\
\text { Yalısı }\end{array}$ & 1803 & 2 ev & (Şehsuvaroğlu, 1986) \\
\hline Köprübaşı & Eylül 1835 & 20 dükkân & (Şehsuvaroğlu, 1986) \\
\hline Beşiktaş & $\begin{array}{l}16 \text { Haziran 1855 (H } \\
10 \text { Şevval 1271) }\end{array}$ & $?$ & (Cezar, 1963) \\
\hline Köyiçi Çeşme Meydanı & 2 Ağustos 1863 & 17 bina & (Akbayar, 1998) \\
\hline Hasfirnn & $\begin{array}{l}\text { 8 Ağustos 1868 (H 27 } \\
\text { Temmuz 1284) }\end{array}$ & 38 bina & (Koçu, 1964) \\
\hline Köprübaşı1 & 1873 & 19 bina & (Göyünç, 1948) \\
\hline Köyiçi & $1854-1908$ aras1 & 51 bina & (Akbayar, 1998) \\
\hline Köyiçi & $\begin{array}{l}19 \text { Mayıs 1892 (H 7 } \\
\text { Mayı 1308) }\end{array}$ & 166 bina & (Koçu, 1964) \\
\hline Sinanpaşa & $\begin{array}{l}\text { 22 Mart 1905 (H 10 } \\
\text { Mart 1320) }\end{array}$ & 20 bina & (Koçu, 1964) \\
\hline Beşiktaş & 1922 & 153 bina & (Kurtçu, 2007) \\
\hline
\end{tabular}

1922 Pervitch haritasındaki doku incelendiğinde özellikle Abbasağa Mahallesi gibi Beşiktaş'ın sırtlarında ızgara plan sistemli kâgir yapı adaları görülmektedir. Bugünkü Milli Saraylar Lojmanına denk gelen amorf arazi alanı üzerine de "tarla" yazılarak haritada da boş bırakılmıştır. Tüm bunlar, yangın sonrası alınan düzenleme kararları ile yapılan değişiklikler olarak yorumlanabilir.

Beşiktaş’ta en önemli kentsel dönüşüm etkisi de hanedana ait olan saray, kasır ve konaklardır. Semtte onaltıncı yüzyılda inşa edilen ilk saray olan Süleyman Sarayı'nın etrafı zamanla Süleymaniye adını almıştır. Saray, onyedinci yüzyılda sahil kısmına taşınmış, yerine cami yapılmak istenmiştir. 1603- 1617'de Dolmabahçe koyu doldurulmuş, burada bulunan yalılar kamulaştırılarak Beşiktaş Sarayı'nın ilk yapıları inşa edilmiştir.

1766 İstanbul Depremi ile de zarar gören saray yapıları aynı hızla onarılmış, yeni yapıların eklenmesi ile bir yerleşke halini almıştır. Ondokuzuncu yüzyılda Beşiktaş'ın saray konusunda üç yerleşke mahali olması, bu semti diğerlerinden farklı kılmıştır. Sahilde Dolmabahçe, Ortaköy yolunda Çırağan ve bunlardan sonra yapılan tepede Yıldız Sarayı; Beşiktaş'ı saray semti haline getirmiştir. 1834'de Sultan II. Mahmut'un yönetimi ile kalıcı bir şekilde Beşiktaş Sarayı'na taşınması, Beşiktaş'ın kaderini değiştirmiştir. Ondokuzuncu yüzyılda inşa edilen bu sarayların Beşiktaş'ın kentsel dönüşümü üzerine etkileri farklıdır. Çünkü önceki düzende yönetim Topkapı Sarayı'nda olup sayfiye, mesire, avlanma alanı olarak Beşiktaş'a gelinmiştir. Bu dönemsel kullanımda Beşiktaş’ta köklü değişimler yaşanmamıştır.

Özellikle Osmanlı yönetiminde ondokuzuncu yüzyılda yaşanan batılılaşma çerçevesinde, yeni imar-bayındırlık hizmetleri nasıl diğer semtlerde görülmüşse Beşiktaş’ta da görülmüştür. Fakat semtin yönetim merkezine ev sahipliği yapması bu süreci özel kılmış; Beşiktaş’ın değişikliklerde önceliğin tanındığı belki de yeniliklerin ilk uygulandığı yer olmasını sağlamıştır. Aynı zamanda hanedana, saraya yakın olma fikri ile burada farklı bir çevre oluşmuş; bu varlıklı kesimin yapıları da Beşiktaş’a yeni ve farklı olarak gelmiştir.

Ondokuzuncu yüzyılda Beşiktaş’ta görülen kentsel dönüşümünde başlıca etkenler yangınlar, saray yerleşkesi, batılılaşan yaşam ve doğal süreçte büyüyen bir yerleşmenin değişimleridir. Bu değişimleri kentsel ölçekte bir başlıkta toplamak gerekirse ilk olarak söylenmesi gereken Hanedanın kaldığı bu semtin bir şekilde sarayın imajını yansıtması gerekliliği ile yapılan düzenlemelerdir. Özellikle sahil kısmının tamamiyle saray erkânına ait olması; Osmanlı yönetici, asker ve memur sınıfını tepelerin sırtlarına itmiştir (Şekil 8). 
Şekil 8: Osman Paşa Konağı, Serencebey (Kurtay, 2001).

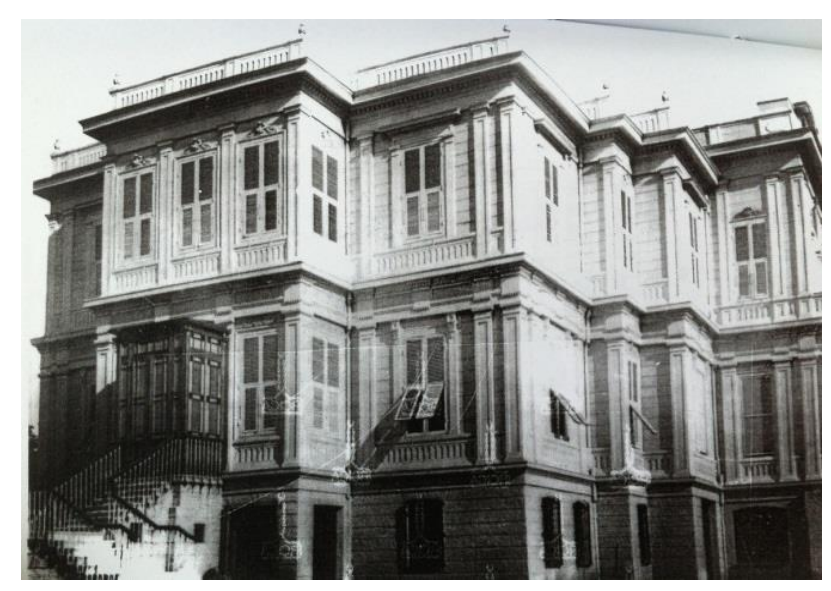

Batılılaşmanın öncelikle yönetimde yaşanması, kuşkusuz mimariyi de etkilemiştir. Beşiktaş sahil kısmındaki saray yerleşkesi, geleneksel konutların oluşturduğu dokudan farklı bir planda yerini alır. Saraya yakın olmak isteyen zengin kesim ve saray erkânı burada bahçe içinde tekil konaklarda ikamet ettikleri için bitişik nizaml, sık, organik gelişmiş geleneksel sokak mahalle dokusu bu etkenle değişmiştir.

Ondokuzuncu yüzyıla damagasını vuran yangınlar; Beşiktaş’taki kentsel dönüşümlerinin başlıca etmenlerindedir. Yangınlar sonrası uygulamalarda, yeni ızgara plan sistemli yerleşmeler topoğrafyaya göre şekillenen yapı adalarının yerini almış; çıkmazlar ve dar sokaklar yerlerini erişimin her şekilde sağlanılmaya çalışıldığı geniş sokaklara bırakmıştır.

Galata ve Pera Bölgesi'nde yaşanan büyümeler sonucu mezarlıklar yeni yerleşim alanlarına dönüşürken Beşiktaş’ta yirminci yüzyılın başına kadar mezarlık alanlarının korunduğu gözlemlenmiştir. En sık doku arasında kalan Abbasağa Mezarlığı'nın parselinde 1930'lara kadar bir değişiklik görülmemiş; Büyük ölçüde benzer biçimde günümüze kadar ulaşmıştır.

Beşiktaş'ta batılılaşma kapsamında yaşanan değişimler, halkın kullandığı geleneksel konutta son bulmuştur. Beşiktaş'ın bir saray yerleşkesi olduğunu vurgularsak; saray ile birlikte gelen saray erkânının, zengin reayanın konutları, batılılaşma ile gelen yeni kâgir konaklar, Beşiktaş’ta görülen tek yapı ölçeğindeki değişim kapsamındadır.

Batı usluplu bahçe içindeki tekil konaklar özellikle Yıldız Sarayı'na yakın mahalle olan Serencebey mevkiinde görülmektedir. Aynı şekilde sarayın tam karşısında da Abbasağa'nın üst kısımlarında, Ihlamur mevkiinde aynı şekilde yapılaşmıştır. Yükselen Galata-Pera'nın varlığı ile aynı atılımın görüldüğü Nişantaşı ve Beşiktaş sınırlarındaki Maçka'da da benzer yerleşimler gelişir (Şekil 9). 
Şekil 9: Yıldız Sarayı 'ndan Abbasă̆a 'ya bakışta görülen kâgir, kemerli pencereli konaklar (Kurtay, 2001:239).

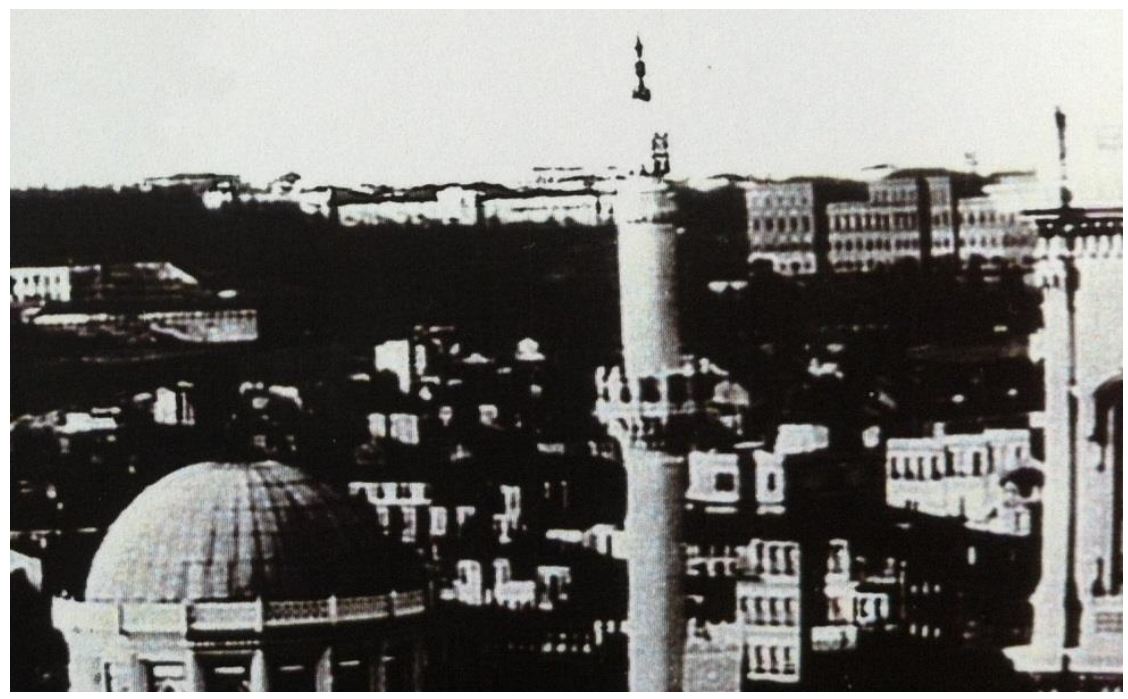

1875 yapım tarihli Akaretler sıra ev grubu konut tipinin İstanbul'daki en önemli ve anıtsal örneğidir. Toplu konut mimarisine sıra evler yaklaşan bu yapı grubu, İstanbul için de ilktir (Şekil 10) (Sağdıç, 1999).

Şekil 10: 1896 tarihli Akaretler siraev yapı grubu görseli (Batur, 1998: 120).

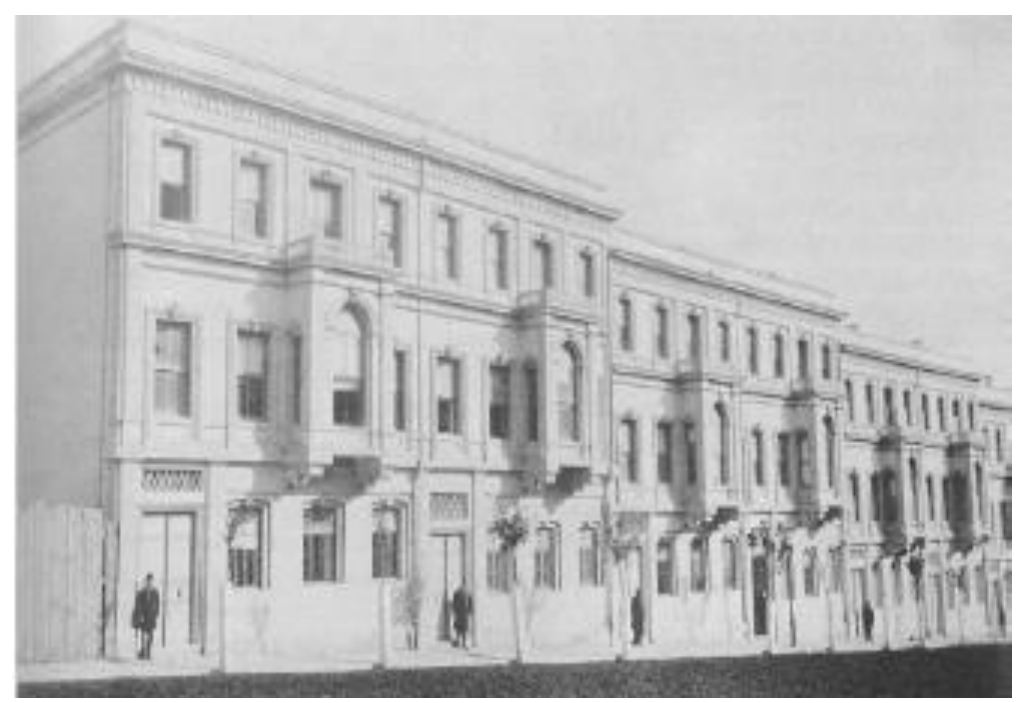

Kentsel ölçekle gelen yeni yollar kendileri ile birlikte kaldırımları, sınırlayıcı yeni elemanları da beraberinde getirmiştir. Peyzajın ele alııı̧ı da bu dönemde görülen yeniliklerdir. Mevcudu kullanan anlayıştan styrılan Osmanlı doğal peyzajı şekillendirmede batı etkileri ile değişime gitmiştir. Bu bağlamda 1880-90 arasında Dolmabahçe- Ortaköy yol aksının ağaçlandırılması bu sürecin bir ürünüdür. Artık yeni kent görüntüsü anlayışı ile değişimler yapılmıştır. Özellikle sınırlayıcı öğeler olarak bahsedilen korkuluklar, bordürler, ihata ve istinat duvarları, sarayın varlığ ile en iyi örneklerini Beşiktaş’ta bırakmıştır (Şekil 11-13). 


\section{CA $\breve{G L A Y A N}$}

Şekil 11: Dolmabahçe sarayı yol aksında görülen kaldırım, ağaçlar ve demir korkuluklar (Kurtay, 2001: 230).

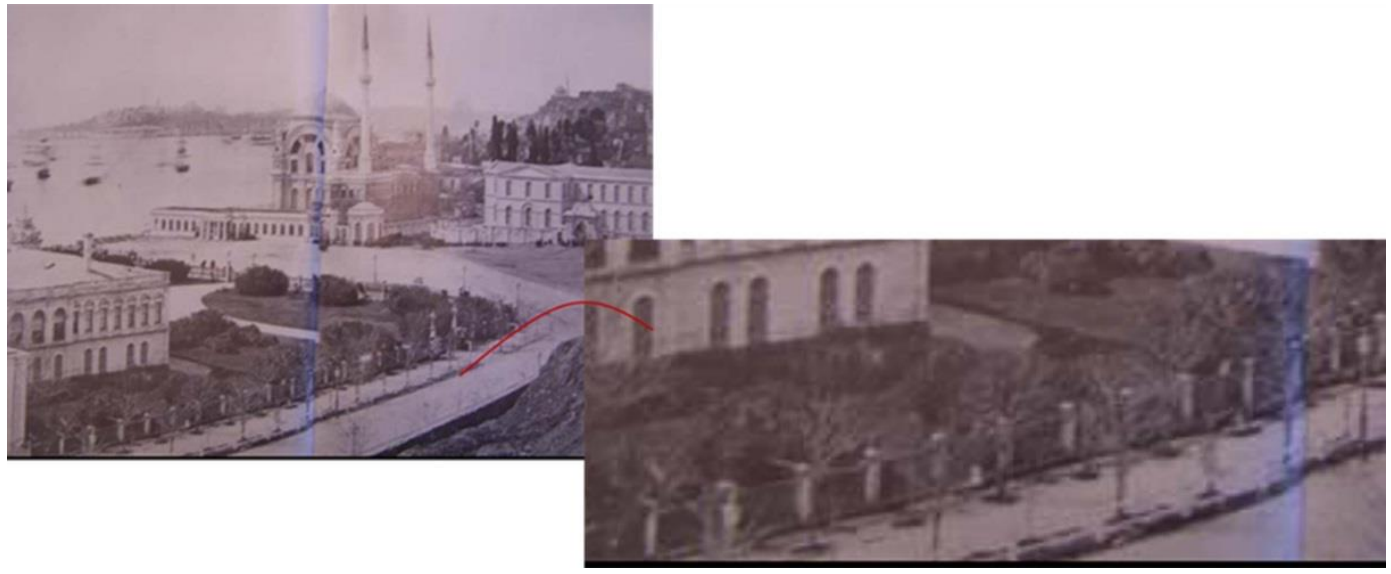

Şekil 12: Yıldız Hamidiye Camii etrafindaki kaldırım ve korkuluklar (Yıldız Fotoğraf Arşivi).

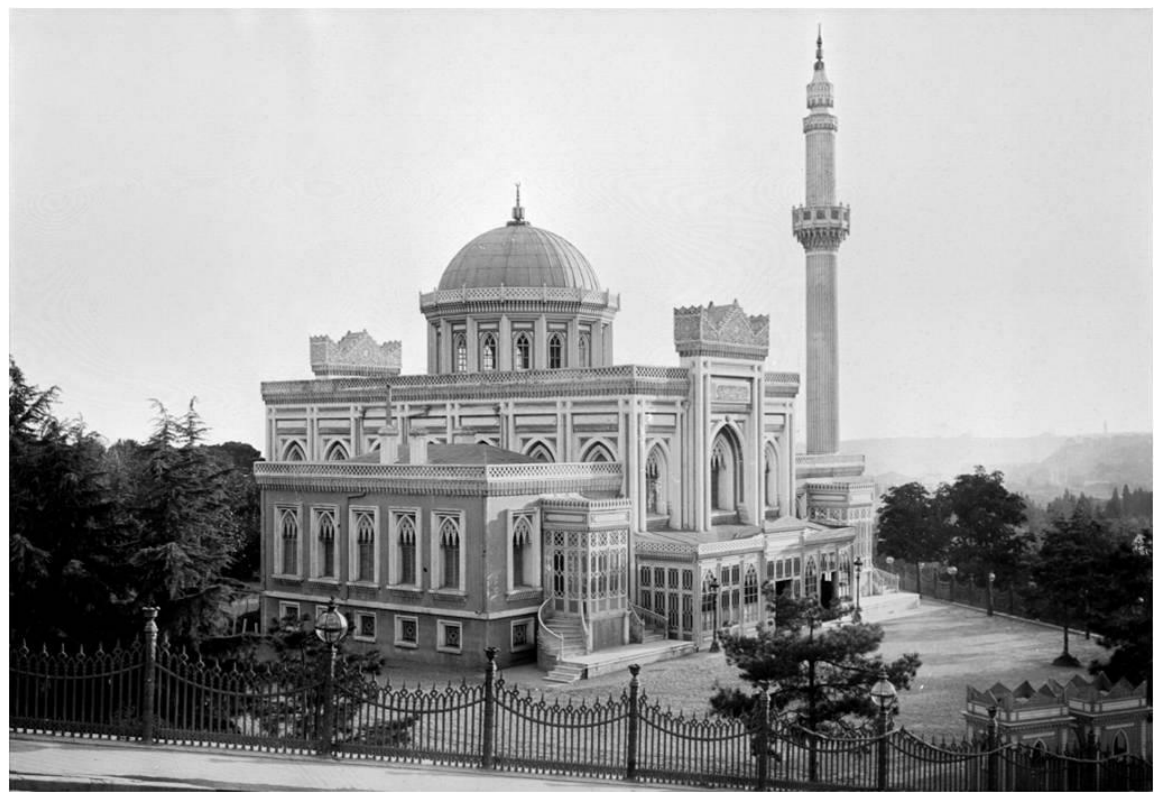


Şekil 13: Yıldız Parkı civarında ondokuzuncu yüzyıldan günümüze kadar gelen peyzaj elamanları (Murat Çă̆layan arşivi).
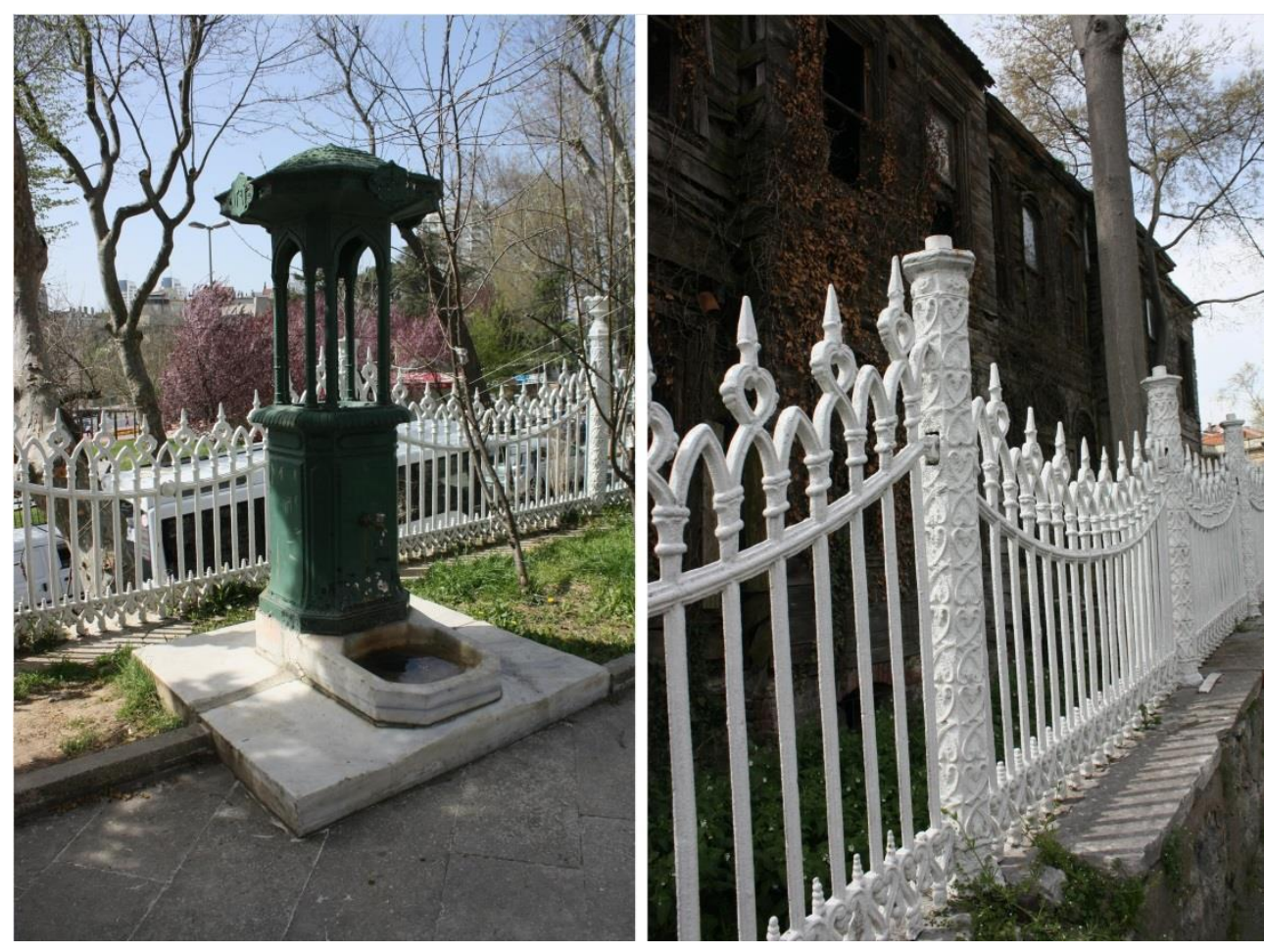

\section{SONUÇ}

Beşiktaş semti, onsekizinci yüzyıla kadar Osmanlı İstanbul'unun genel görüntüsü olan ahşap evler ve organik sokak yapısı ile varlığını sürdürmüştür. On sekizinci yüzyıldan sonra saray yapılarının buraya yerleşmesi ile hanedanın dönemsel kullanımlarına ev sahipliği yapan Beşiktaş, diğer yerleşmelerden bu yönüyle farklılık göstermiş olsa da genel olarak dokusu değişime uğramamıştır. Ondokuzuncu yüzyıla gelindiğinde hanedanın kalıcı bir şekilde Beşiktaş Sarayı'na yerleşmesi, Beşiktaş için bir dönüm noktasıdır. Osmanlı üst yönetimi, batılılaşmayı yaşadığı bu süreçte semte somut mimari izler bırakmıştır.

Bütün olarak saray çevresinde gelişen yerleşme bir doğrultuda; Galata- Pera’ya yakın olan Nişantaşı ve Maçka ise başka bir doğrultuda Beşiktaş’ın iki yönlü gelişim aksını oluşturmuştur. Saraya yakın olma düşüncesi ile saray erkânı ve zengin halkın da rağbet ettiği Beşiktaş artık on dokuzuncu yüzyılın gözde bir semtidir. Yeni konaklar, saraylar organik doku arasında yer almaya başlamışlardır. Bir yandan da yangınlarla kısmi kayıpların yaşandığı dokuda artık bir dönüşüm söz konusudur. Yangın sonrası düzenlemelerde organik dokunun yerini ızgara planlı kâgir yapı adaları topoğrafyaya aykırı olsa da yerini almıştır. Değişimler sadece dokuda değil tek yapı ölçeğinde de yaşanmış; batılı usluptaki yeni konaklar saray çevresi yerleşmelerinde görülmektedir.

İstanbul'un genel çehresinde görülen değişim ve dönüşümler saray olgusu ile Beşiktaş’ta hızlı yaşanmıştır. Bu yüzyılda kentsel dönüşümleri, mimariyi dolayısıyla sosyal yapıyı ve ekonomik durumu etkileyen döngüsel bir süreç tanımlanabilir. Başka bir ifadeyle Beşiktaş'a sarayla birlikte gelen zengin halkın ekonomik gücü ve sosyal yaşantısı mimariye, kentsel ve sosyal dokuya yansımıştır. 


\section{KAYNAKÇA}

Akbayar, N. (1998). Beşiktaş Tarihi, Dünden Bugüne Beşiktaş. İstanbul: Beşiktaş Belediye Başkanlığı Yayınları.

Banoğlu, N. A. (2008). Tarihi ve Efsaneleriyle Istanbul Semtleri. İstanbul: Selis Kitaplar.

Batur, A. (1998). Akaretler, Dünden Bugüne Beşiktaş. İstanbul: Beşiktaş Belediye Başkanlığg.

Cezar, M. (1963). Osmanlı Devrinde İstanbul Yapılarında Tahribat Yapan Yangınlar ve Tabii Afetler. Türk Sanatı Tarihi Araştırma ve İncelemeleri I, İstanbul, s. 374-390.

Cezar, M. (2002). Osmanlı Başkenti. İstanbul: Erol Kerim Aksoy Kültür, Eğitim, Spor ve Sağlık Vakfı Yayını.

Dağdelen, İ. (2006). Alman Mavileri, 1913-1914: I. Dünya Savaşı Öncesi İstanbul Haritaları. İstanbul: İstanbul Büyükşehir Belediyesi Yayınları.

Denel, S. (1982). Batılılaşma Sürecinde İstanbul'da Tasarım ve Dış Mekânlarda Değişim ve Nedenleri. Ankara: ODTÜ Mimarlık Fakültesi Ara Yayınları.

Evliya, Çelebi. (1998). Evliyâ Çelebi Seyahatnâmesi I. Kitap Topkapı Sarayı Kütüphanesi Bağdat 304 Numaralı Yazmanın Transkripsiyonu Dizini, (Hazırlayanlar: Robert Dankoff, Seyit Ali Kahraman, Yücel Dağlı), İstanbul: Yapıkredi Yayınları.

Eyice, S. (1976). Bizans Devrinde Boğaziçi. İstanbul: İstanbul Üniversitesi Edebiyat Fakültesi Yayınevi.

Ayvansarayi H. E. - Ali S. E., Süleyman B. E. (2001). Hadikatü'l Cevami İstanbul Camileri ve Diğer Dini-Sivil Mimari Yapılar (Derleyen: Ahmet Nezih Galitekin). İstanbul: İşaret Yayınları.

Gökyay, D. (2009). Beşiktaş Köyiçi Kentsel Sit Alanının 20. Yüzyıl Başından Günümüze Değişimi ve Korunması İçin Öneriler. Yayımlanmamış Yüksek Lisans Tezi, İstanbul: İstanbul Teknik Üniversitesi, Fen Bilimleri Enstitüsü.

Göyünç, N. (1948). Beşiktaş’ın Tarihi (Fetihten zamanımıza kadar). Yayımlanmamış Yüksek Lisans Tezi, İstanbul: İstanbul Üniversitesi Edebiyat Fakültesi Tarih Bölümü.

Kırdar, L. (1947). Yenileşen İstanbul (1939 Başından 1947 Sonuna Kadar İstanbul'da Neler Yapıldı?). İstanbul: İstanbul Büyükşehir Belediye Matbaası.

Koçu, R. E. (1964). Beşiktaş Yangınları. İstanbul Ansiklopedisi. C. V, İstanbul: İstanbul Ansiklopedisi ve Neşriyat Kollektif Şirketi, s. 2597-2598.

Kurtay, N. (2001). Istanbul'da 19. Yüzyll Kentsel Yaşamına Koşut Olarak Değişen Saray Ve Konut Mimarlı̆̆ı. Yayımlanmamış Yüksek Lisans Tezi, İstanbul: İstanbul Teknik Üniversitesi, Sosyal Bilimler Enstitüsü.

Kurtçu, Ü. (2007). Boğaziçi Tiryakiliği. Ankara: Elips Kitap.

Metin, A. B. (2010). Beşiktaş’ın Kentsel Tarihi ve Barındırdı̆̆ Mimari Eserler. Yayımlanmamış Yüksek Lisans Tezi, İstanbul: Mimar Sinan Güzel Sanatlar Üniversitesi, Sosyal Bilimler Enstitüsü.

Özyurt. E. (2007). 19. Yüzyılın İkinci Yarısı ve 20. Yüzyıl Başındaki Yangınlar Sonrası Galata'da Kentsel Dokunun Değişimi ve Korunmuşluk Durumunun İncelenmesi. Yayımlanmamış Yüksek Lisans Tezi, İstanbul: İstanbul Teknik Üniversitesi, Fen Bilimleri Enstitüsü. 
Sağdıç, Z. (1999). Sıraev Kavramının İncelenmesi ve Osmanlı Mimarisinde Akaretler Sıraev Grubunun Yeri ve Önemi. Yayımlanmamış Yüksek Lisans Tezi, İstanbul: İstanbul Teknik Üniversitesi, Fen Bilimleri Enstitüsü.

Şehsuvaroğlu, H.Y. (1986). Boğaziçine Dair. İstanbul: Türkiye Turing ve Otomobil Kurumu.

Url 1: https://sehirharitasi.ibb.gov.tr/ (Erişim Tarihi: 10.03.2020)

Url 2: http://www.istanbulkulturenvanteri.gov.tr/harita/tarihi?open[kauffer]=1 (Erişim Tarihi: 18.03 .2020$)$ 


\section{EKLER}

Ek 1: Kauffer Haritasında Beşiktaş 1786 (Url 1).



Ek 2: Hellert Kauffer Haritasında Beşiktaş 1836 (Url 1).

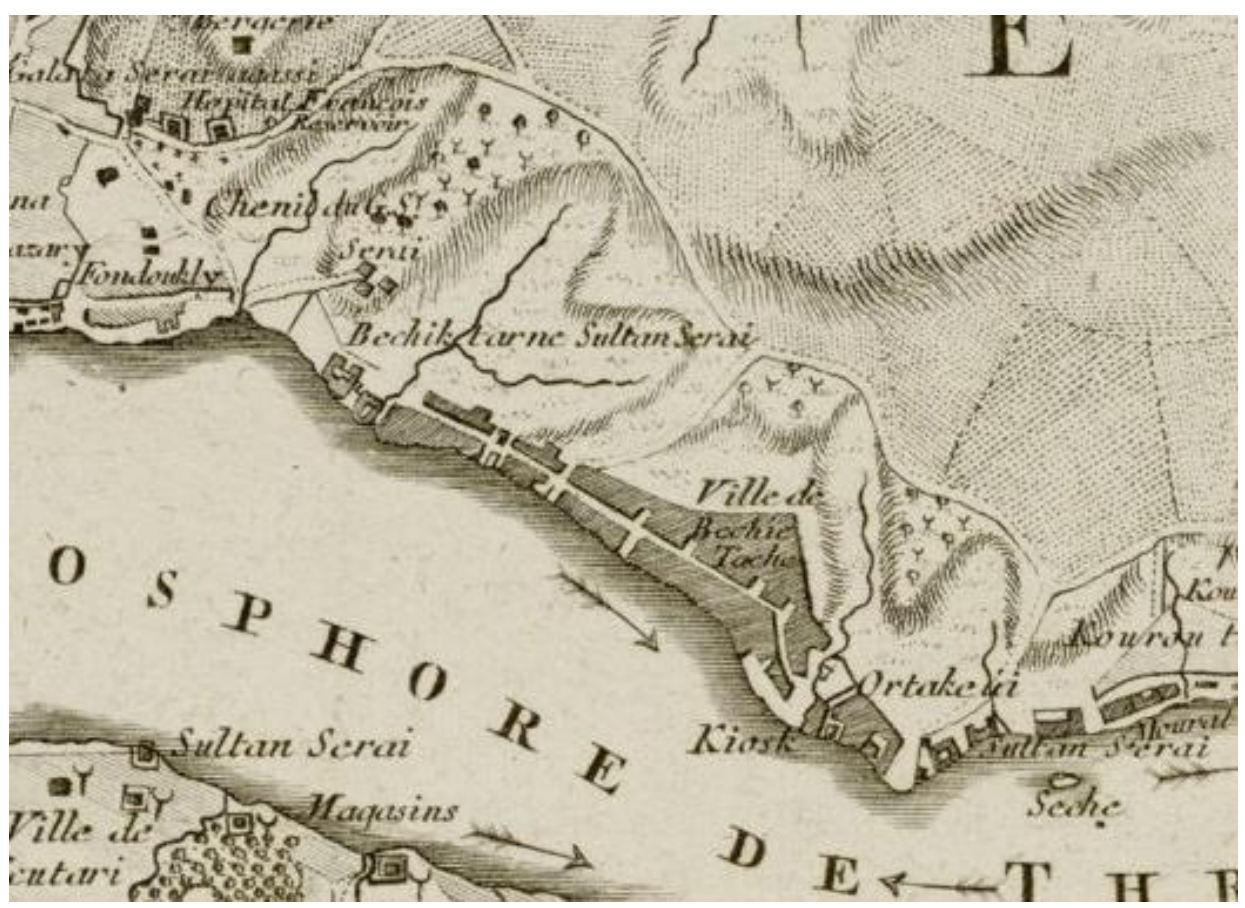


Ek 3: Moltke Haritasında Beşiktaş 1836 (Url 1).

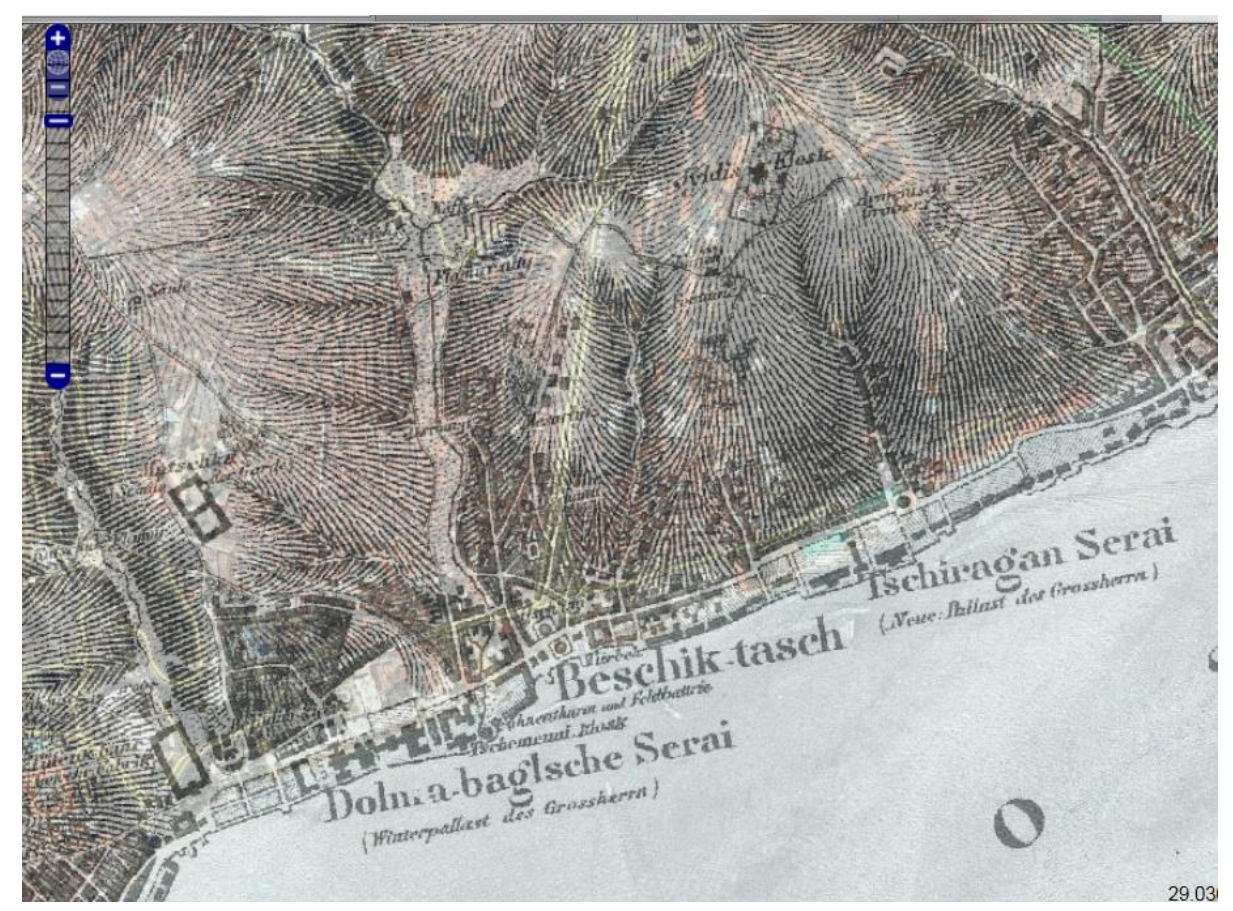

Ek 4: Osmanlı Haritasında Beşiktaş 1909 (Url 1).

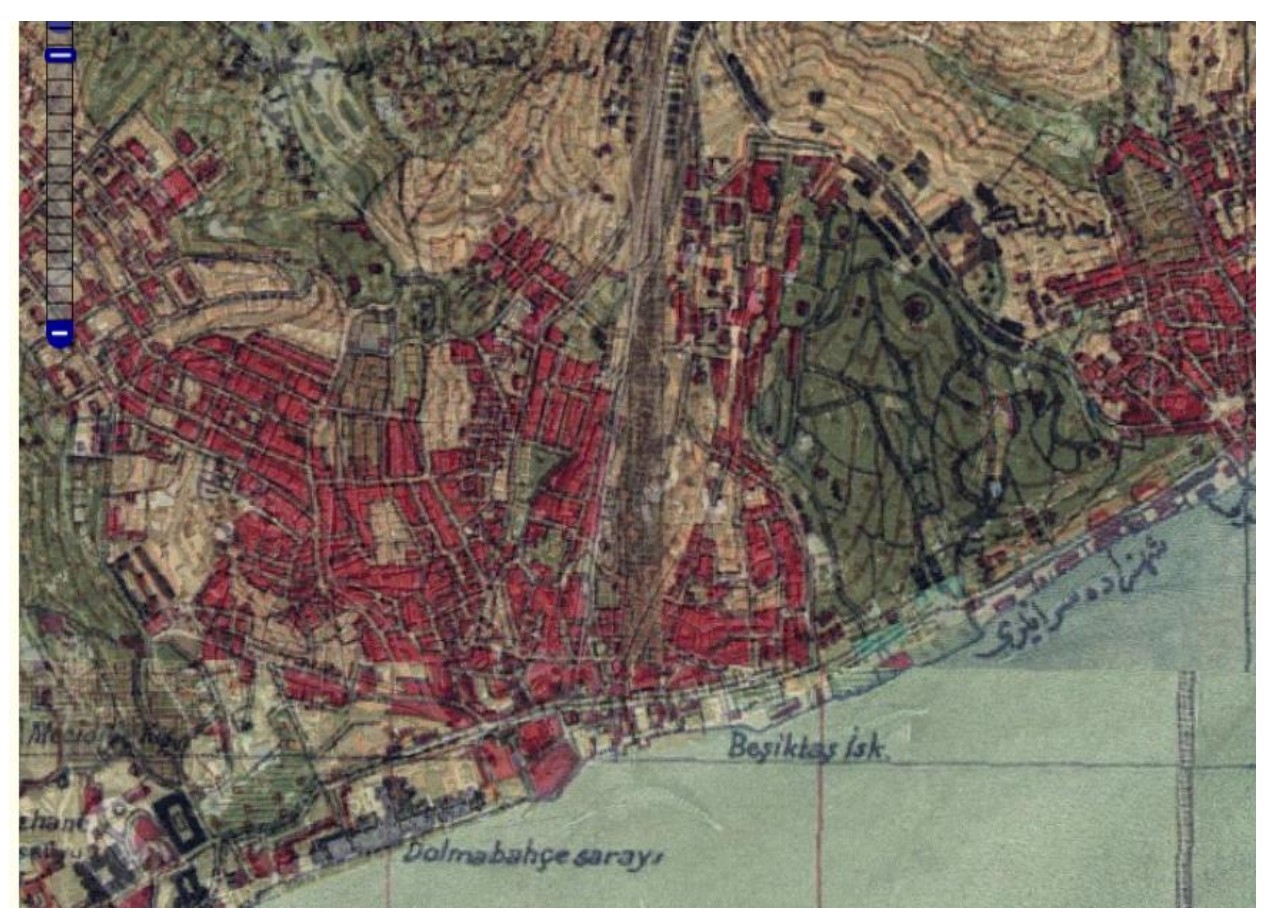


Ek 5: Alman Mavileri Haritalarında I.Dünya Savaşı Öncesi Beşiktaş 1913-1914 (Dağdelen, 2006).

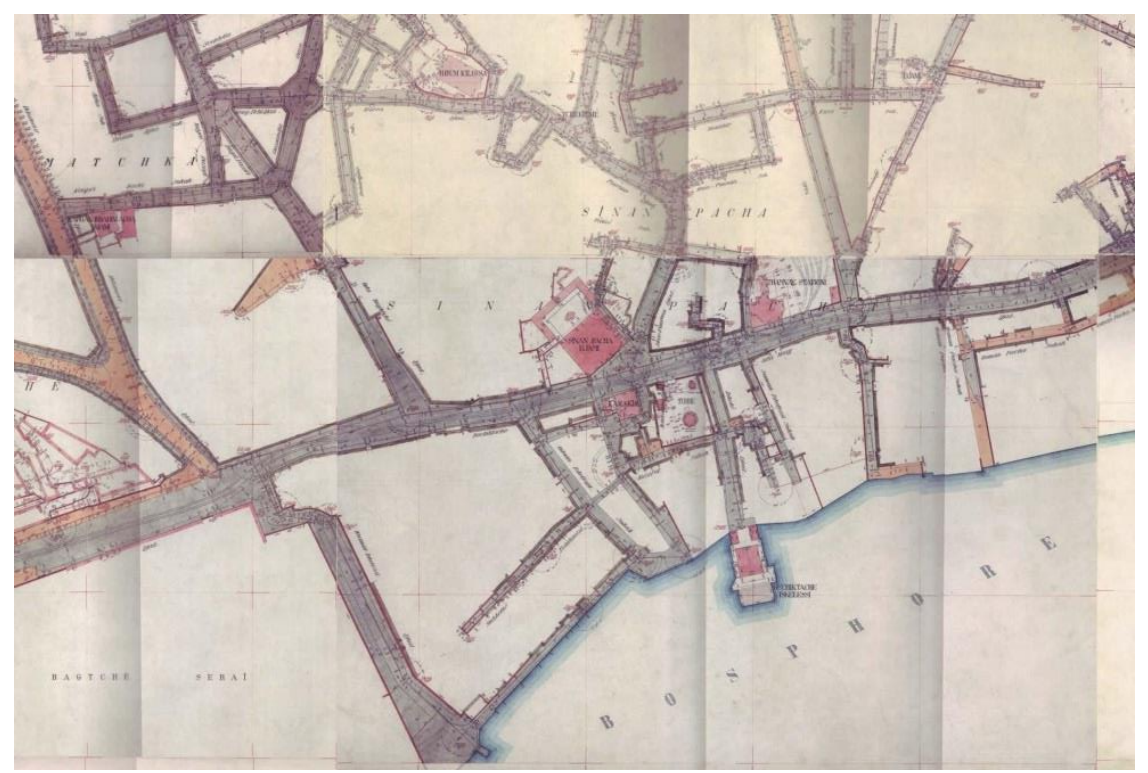


Ek 6: Çalışma alanı ve 1922 Pervitich Haritasının çakıştırılmış görüntüsü

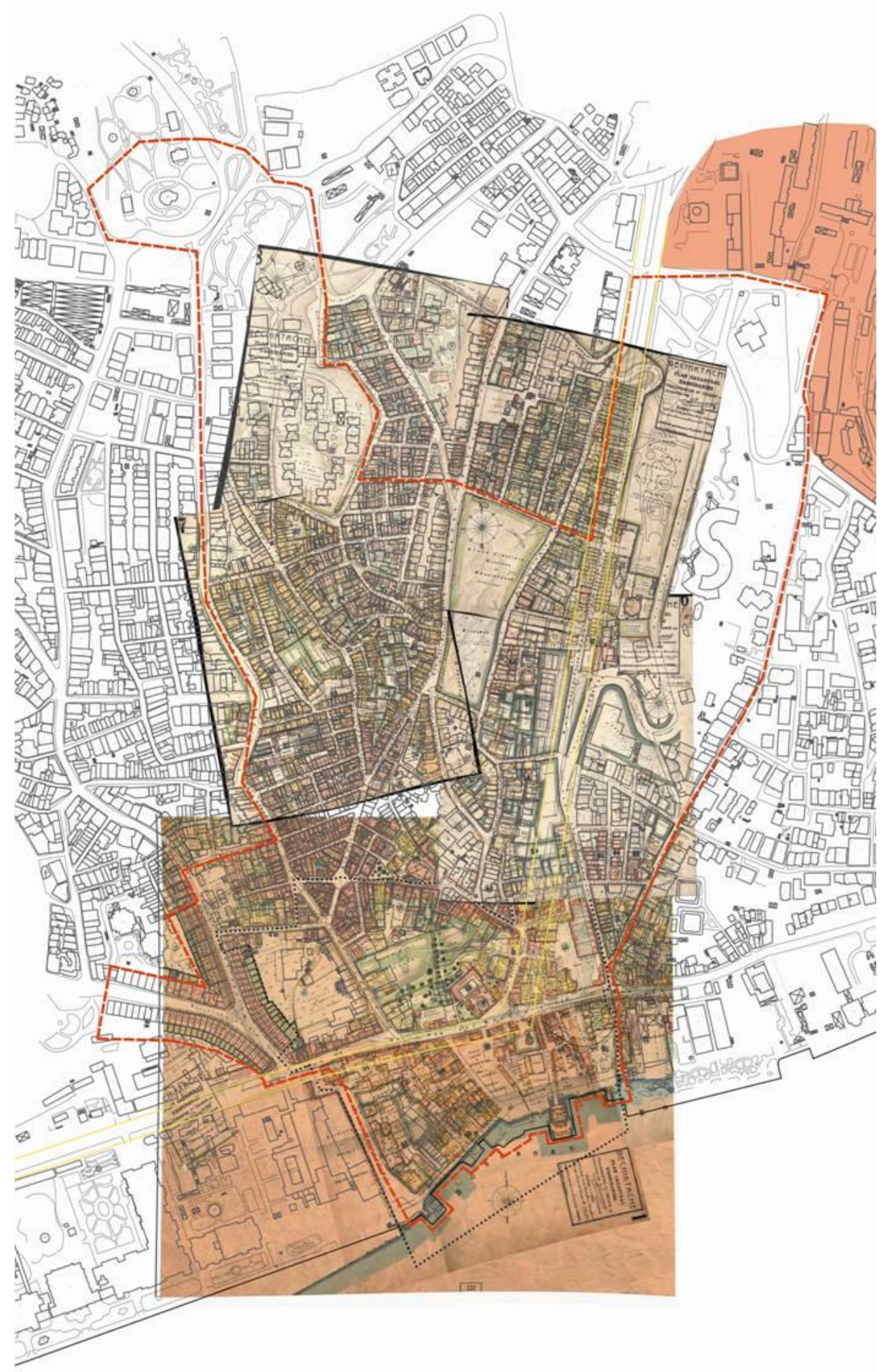

